\title{
MENILIK PERKEMBANGAN PEMIKIRAN POLITIK ISLAM MASA MODERN \\ (Sebuah Pembacaan Awal)
}

\author{
Oleh: \\ Vita Fitria \\ MKU UNY \\ email: vitafitria08@gmail.com
}

\begin{abstract}
Abstrak: Pembacaan pemikiran politik Islam masa modern berdasarkan ijtihad tokoh-tokoh pembaru akan mampu meletakkan dasar historis serta pembacaan kritis tentang kondisi politik kekinian. Melalui pengkajian terhadap pemikiran beberapa tokoh, pemikiran politik Islam masa modern cenderung didominasi oleh gejala fundamentalisme. Namun, setelah para sarjana mengembangkan beberapa aspek kajian, pemikiran politik Islam masa modern seakan menjadi titik pijak pilihan bernegara oleh umat Islam. Paradigma "simbiotik" antara guru dan murid ini kemudian menawarkan pencerahan untuk kondisi kontemporer saat ini.
\end{abstract}

Kata Kunci: Politik Modern, Reformasi Pemerintah, Pemikiran Tokoh

\section{Pendahuluan}

Munawir Sjadzali (1993: 115), menyebut terdapat tiga hal yang melatarbelakangi munculnya pemikiran politik modern (kontemporer) pada akhir abad 19 M. Pertama, kemunduran dan kerapuhan dunia Islam yang disebabkan oleh faktor-faktor internal, yang berakibat munculnya gerakan pembaruan dan pemurnian. Kedua, rongrongan Barat terhadap keutuhan kekuasaan politik dan wilayah dunia Islam yang berakhir dengan dominasi atau penjajahan oleh Dunia Barat atas sebagian besar wilayah Islam, dengan akibat rusaknya hubungan antara Islam dan Barat, dan berkembangnya sikap anti Barat dari umat Islam. Ketiga, keunggulan Barat dalam bidang ilmu, teknologi dan organisasi.

Adanya reformasi pemerintahan terutama pada abad ke-19, membawa dampak pada perubahan bagi hukum dan kelembagaan Islam. Perubahan itu terlihat dari yang semula berdasarkan pada legitimasi Islam kini sudah mengalami interaksi dengan pola pikir Barat. yang disikapi dengan berbagai corak respon. Sebagian pemikir politik Islam menghargai dan akomodatif terhadap pemikiran 
Barat. Namun, ada juga yang menentangnya, ataupun mengedepankan paradigma baru pemikiran politik Islam (M. Din Syamsuddin, 2000: 165).

Dalam kaitannya dengan politik, Jamaluddin al-Afgani menghendaki reformasi dan pembaruan politik Islam dengan mengganti bentuk khilafah menjadi republik. Namun, dia tidak mengurai lebih jauh tentang kelanjutan dari sistem pemerintahan yang ia tawarkan. Baginya, kebangkitan dan reformasi umat Islam tergantung pada permasalahan politik, yakni kebebasan dari kungkungan kolonial. Afgani menyatakan bahwa Islam memberikan ikatan yang umum dan teramat fundamental dan merupakan basis bagi solidaritas umat Islam (John L. Esposito, 1990: 66).

Berbeda dengan Afgani, Muhammad Abduh (1849-1905), salah seorang muridnya, tidak terlalu memperdulikan bentuk bentuk pemerintahan. Menurut dia, jika sistem khalifah masih tetap menjadi pilihan model pemerintahan, maka bentuk ini harus bersifat dinamis yakni mengikuti perkembangan masyarakat dalam kehidupan materi dan kebebasan berpikir. Sebagai dampak positifnya, umat Islam mampu mengantisipasi dinamika zaman. (Muhammad Azhar, 1996: 108)

Menurutnya, Islam tidak mengenal adanya kekuasaan agama, dalam arti: a) Islam tidak memberikan mandat kepada siapapun untuk menindak orang lain atas nama agama atau Tuhan, b). Islam tidak membenarkan campur tangan penguasa dalam urusan agama, c). Islam tidak mengakui hak seseorang untuk memaksakan penafsirannya tentang agama.

Pada taraf ini terjadi pergeseran pemikiran dari pola pikir para pemikir politik Islam masa pramodern yang menyatakan bahwa kekuasaan atau khalifat itu mandat dari Allah. Menurut Abduh, kekuasaan politik harus didasarkan pada kedaulatan rakyat. Dan kedaulatan rakyat ini dibangun atas prinsip-prinsip: a. kebebasan, b. demokrasi dan c. konstitusi yang berfungsi sebagai landasan sistem politik dalam pemerintahan. (M. Din Syamsuddin, 2000: 167).

Islam menurut Abduh dianggap memiliki unsur-unsur dinamis yang dapat disesuaikan dengan dinamika zaman lewat jalan ijtihad. Pandangan Abduh ini sedikit banyak mempengaruhi pemikiran generasi berikutnya yang cenderung ke 
arah paham nasionalisme dan sekularisme, seperti Ahmad Lutfi Sayyid, Saad Zaghlul, Thaha Husein dan Ali Abd Raziq.

Adapun pemikiran politik Rasyid Ridha (1865-1935), justru cenderung ke arah tradisionalisme daripada modernisme. Dalam bukunya al-Khilafah au alImamah al-Uzhma Ridha menegaskan bahwa jabatan khalifah perlu dihidupkan kembali melalui ahl hall wa al-aqd. Baginya, jabatan khalifah merupakan kewajiban syara' yang eksistensinya sangat penting dalam rangka penerapan hukum Islam yang terjamin dan terhindar dari berbagai bahaya, karena bentuk pemerintahan yang lain menurutnya tidak mampu menerapkan syari'at Islam (Muhammad Azhar, 1996: 110).

Rasyid Ridha menerapkan prinsip "delegation of authority" yang berarti hubungan antara rakyat dengan penguasa tidak dalam kerangka absolut tapi lebih kepada amanat. Nampaknya ini yang membedakan Ridha dengan para pemikir masa pramodern. Menurut Ridha, hubungan antara 'wakil' dan 'yang diwakili' atau ahlul hal wal aqd dan ummah, adalah hubungan yang menunjukkan bahwa kedaulatan umat telah didelegasikan kepada ahlul hal wal aqd yang tentunya adalah wakil-wakil, bukan utusan-utusan (M. Din Syamsuddin, 2001: 121). Dalam hal ini Ridha tidak memandang bahwa lembaga khilafah dan figur khalifah itu kebal terhadap hukum serta tidak dapat dilakukan impeachment terhadapnya sebagaimana pendapat Sunni, dalam kondisi dan atas dasar-dasar tertentu impeachment bisa dilakukan. Menurut Ridha, harus diadakan perlawanan terhadap kezaliman dan ketidakadilan khalifah, dan kalau kepentingan umat di bahayakan, kekuasaan bisa digulingkan dengan perang atau kekerasan sekalipun. (Munawir Sjadzali, 1993: 134).

Dalam kaitannya dengan menghidupkan kembali lembaga kekhalifahan, Rasyid Ridha mengemukakan gagasan-gagasan program pelaksanaannya yaitu: a). Tempat kedudukan khalifah baru, menurutnya adalah tempat yang strategis dan secara geografis berada di tengah dunia Islam, b). Cara mempersiapkan calon Khalifah, salah satu syarat utama bagi seorang khalifah atau ahlul halli wal aqdi adalah berpengetahuan luas dan mampu berijtihad, c). Diadakannya muktamar Islam yang dihadiri oleh wakil-wakil negara Islam seluruh dunia. Muktamar 
tersebut pernah diselenggarakan di Mesir tahun 1926, namun gagal karena tidak dapat tercapai satu kesepakatan (Munawir Sjadzali, 1993: 13-136).

Kalau Ridha dengan obsesinya menghidupkan kembali kekhalifahan yang ideal (Idealisme Tradisional), Abu Kalam Azad (1888- 1958) di India mempertahankan "Realisme Tradisional", dalam arti ingin mendukung bentuk tradisional pemerintahan Islam, yakni sebagaimana terwujud dalam pemerintahan aktual, kekhalifahan Turki Usmani. Abu Kalam Azad menjelaskan bahwa kekhalifahan sebagai pengganti nabi dalam urusan duniawi, adalah satu-satunya bentuk pemerintahan yang sah. Pentingnya pembentukan lembaga ini adalah untuk mengarahkan umat Islam pada jalan yang lurus, untuk menegakkan keadilan, menciptakan perdamaian dan menyebarkan Firman Allah di muka bumi. Pandangan ini didasarkan atas suatu keyakinan bahwa Islam adalah agama universal, dan kekhalifahan adalah lembaga keagamaan dan politik yang dengannya umat Islam di seluruh dunia dapat mempertahankan solidaritas universal (M. Din Syamsuddin, 2001: 123-125).

Menurut Muhammad Husein Haikal (lahir tahun 1888), prinsip-prinsip dasar kehidupan kemasyrakatan yang diberikan oleh al-Quran dan Sunnah tidak ada yang langsung berkaitan dengan ketatanegaraan. Kehidupan bernegara bagi umat Islam dimulai pascanabi hijrah dan menetap di Madinah. Menurutnya, setelah kedudukan umat Islam di Madinah mapan, Nabi juga tidak merubah pola pemerintahan yang ada. Apa yang sering terjadi adalah apabila turun wahyu, maka Nabi mengarahkan umat sesuai dengan petunjuk wahyu tersebut, tanpa bergeser dari prinsip-prinsip dasar pemerintahan yang sudah ada.

Menurutnya, di dalam Islam tidak ada sistem pemerintahan yang baku. Umat Islam bebas menganut sistem pemerintahan apapun asal sistem tersebut menjamin persamaan antar warga negara, dengan berpegang pada tata nilai moral dan etika yang diajarkan Islam bagi peradaban manusia (Munawir Sjadzali, 1993: 188).

Ali Abd Raziq (1888-1966), dalam bukunya Al-Islam wa Ushul al-Hukm memperkenalkan teori yang tidak hanya mengkritik keabsahan kekhalifahan, tapi juga mempertanyakan dasar-dasar kekuasaan Islam. Pokok-pokok pikirannya 
adalah sebagai berikut: Pertama, bahwa nabi tidak membangun negara dan otoritasnya murni bersifat spiritual, Kedua, Islam tidak menentukan sistem pemerintahan yang definitif. Karena itu umat Islam bebas memilih bentuk pemerintahan apapun yang mereka rasakan cocok. Ketiga, bahwa tipe-tipe pemerintahan pasca wafatnya nabi tidak memiliki dasar dalam doktrin Islam. Sistem itu semata-mata diadopsi oleh orang-orang Arab yang dinaikkan derajatnya dengan istilah khilafah untuk memberi legitimasi religius. Keempat, bahwa sistem ini telah menjadi sumber tipuan bagi sebagian besar persoalan dunia Islam, karena ia digunakan untuk melegitimasi tirani dan menimbulkan dekadensi umat Islam. (Abdelwahab El-Affendi, 2001: 45).

Menurutnya, kekuasaan Nabi Muhammad atas kaumnya adalah kekuasaan spiritual (ruhaniah), sumbernya adalah keimanan yang ada dalam hati. Ketundukan terhadapnya adalah ketundukan sejati yang meliputi fisik dan ruhani. Sedang kekuasaan seorang khalifah adalah kekuasaan fisik yang bersifat jasmaniah tanpa ada sedikitpun hubungan hati nurani (Yusdani, 1997: 91). Baginya, mendirikan kekhalifahan adalah tidak wajib bagi umat Islam, karena pada dasarnya hanya berdasarkan pada ijma', sedang ijma' sendiri tidak disebutkan dalam al-Qur'an (Yusdani, 1997: 92).

Pendapat Abd Raziq yang sangat sekuler ini banyak dikecam oleh kaum intelektual di zamannya. Rasyid Ridha adalah tokoh paling keras menentang pendapat sekuler Ali Abd Raziq. Konon antara lain disebabkan waktu penerbitan buku tersebut bersamaan dengan diadakannya Muktamar Akbar Islam di Kairo dalam rangka cita-cita menghidupkan kembali lembaga kekhalifahan (Munawir Sjadzali, 1993: 139).

Bertentangan dengan konsep Ali Abdur Raziq yang memisahkan agama dengan negara, Abul A'la al-Maududi (1903-1979) memunculkan konsep “teodemokrasi”. Pokok-pokok pikirannya tentang negara dan pemerintahan Islam amat lengkap dan rinci. Keyakinan dasar yang melandasi pemikiran Maududi tentang pemerintahan Islam adalah, pertama, Islam adalah suatu agama yang lengkap dan paripurna, mengatur semua aspek kehidupan termasuk politik. Kedua, kedaulatan/kekuasaan tertinggi ada di tangan Allah, untuk itu sebagai 
manifestasinya manusia dan negara harus tunduk kepada al-Qur'an dan Sunnah Nabi. Ketiga, sistem politik Islam adalah sistem universal serta tidak mengenal ikatan/batasan geografi,bahasa dan kebangsaan (Munawir Sjadzali, 1993: 168).

Dari tiga keyakinan dasar tersebut, pokok-pokok pikirannya tentang konsep kenegaraan sebagai berikut, pertama, sistem kenegaraan Islam tidak dapat dikatakan demokrasi (sepenuhnya di tangan rakyat), melainkan "teodemokrasi". Artinya, umat Islam memiliki kedaulatan rakyat yang terbatas pada ketentuan alQur'an dan Sunnah. Kedua, negara harus didasarkan pada sebuah ideologi yang bertujuan untuk menegakkan ideologi tersebut. Sebagai konsekuensinya, bahwa badan eksekutif harus dibentuk oleh umat Islam dan merekalah yang berhak memecat pemerintah dari jabatannya. Ketiga, kekuasaan negara dilakukan oleh tiga badan yang disebut trias politika, legislatif, eksekutif dan yudikatif (Muhammad Azhar, 1996: 134-139).

Idealisme Maududi mengenai Islam melahirkan 'totalitarisme Islam'. Negara Islam menurutnya adalah betul-betul antithesis bagi demokrasi Barat yang sekuler. (John L. Esposito, 1990: 66). Di sini Maududi juga menerapkan sistem syura bagi umat Islam dalam berbuat dan mengambil keputusan. Bentuk pemerintahan "teodemokratis" ini adalah pemerintahan demokrasi illahiyah yang mana umat Islam diberi kedaulatan rakyat terbatas di bawah kemahakuasaan Allah (M. Din Syamsuddin, 2001: 142). Menurut Maududi, Negara Islam bersifat universal dan Ideologis, universal dalam arti mencakup seluruh aspek kehidupan dan pada dasarnya bersifat totalitarian, sedang ideologis dalam arti di dasarkan pada satu ideologi yaitu ideologi Islam. Untuk mendirikan negara Islam juga perlu diadakan revolusi Islam. Dengan ini akan tercipta kesadaran sosial dan iklim moral yang sesuai dengan tuntutan ideologi Islam.

Pola pemikiran Maududi merupakan kombinasi dari pemahaman Islam ortodoks, sikap politik yang fundamentalis dan tidak mau kompromi terhadap Barat (Muhammad Azhar, 1996: 133). Paradigma politik ini biasa disebut dengan paradigma fundamentalis yang menekankan universalisme dan universalitas pandangan dunia Islam yang dapat dikedepankan seabagai alternatif dari kegagalan-kegagalan konsep ideologi modern. 
Jika Maududi menekankan pada "Sistem Pemerintahan", maka Sayid Qutb (1906-1966) mengangkat konsep "Pandangan Dunia Islam" sebagai Ideologi Islam. Pandangan dunia Islam yang dirumuskan oleh Qutb mencakup enam prinsip yang terstruktur bagaikan piramida. Yang berada pada bagian dasar piramida adalah (a).Ketuhanan dan (b). Doktrin keesaan Tuhan. Empat prinsip lainnya adalah (c). Ketetapan (d). Kesempurnaan (e). Keseimbangan (f). Kepastian dan pragmatisme. Dalam persepsi Qutb, karateristik tersebut secara alami bisa dikaitkan dengan asal usul pandangan dunia Islam ketika menghadapi atau berlawanan dengan ideologi yang bertentangan (M. Din Syamsuddin: 2001: 145).

Idealisasi Islam Qutb tampak ditujukan agar Islam menjadi ideologi bagi dunia modern. Pandangan dunia Islam atau ideologi Qutb diartikan sebagai dasar bagi sebuah negara Islam. Menurutnya, tipe pemerintahan semacam ini harus didirikan dengan memperhatikan kepentingan umat Islam yang harus merealisasikan pandangan dunia Islam (M. Din Syamsuddin, 2001: 146).

\section{Pemikiran Politik}

Mencermati perkembangan pemikiran politik masa modern, gerakan pembaruan pemikiran Islam mulai terindikasi pada masa Jamaluddin al-Afgani, dan oleh Muhammad Abduh, pembaruan tersebut semakin ditegaskan dengan konsep rasionalismenya. Pendapat Abduh ini dilatarbelakangi oleh mandegnya pemikiran masyarakat muslim waktu itu. Hal ini disebabkan sistem pemerintahan yang absolut dan sewenang-wenang. Menurut Abduh, syari'ah Islam itu mempunyai dua pengertian. Dalam arti sempit yaitu berupa ketetapan-ketetapan Allah dan Rasul yang tidak bisa diubah lagi. Sementara dalam pengertian luas, adalah kaidah-kaidah atau dasar-dasar yang mengatur kehidupan bermasyarakat yang selalu berkembang untuk kemaslahatan umat (Muhammad Azhar, 1996: 109).

Nampaknya pemikiran Abduh ini juga akibat interaksinya dengan pemikiran Barat, seperti kita tahu, Abduh pernah beberapa tahun dibuang dan tinggal di Perancis bersama gurunya, Jamaluddin al-Afgani. Dia yakin bahwa dengan 
mengadakan reformasi bagi umat Islam, serta mengambil apa yang bermanfaat dari negara Barat, akan memberi nuansa penafsiran baru terhadap cara pikir umat Islam. Hal ini mengantarkannya pada kompleksitas dunia yang semakin berkembang. Ide-ide Abduh tentang konsep kenegaraan menunjukkan kecenderungan pada demokrasi yang tidak mengarah pada pengabaian terhadap syari'ah ataupun pemisahan antara Islam dan negara. Reformasi politiknya masih dalam kerangka ajaran Islam.

Mengikuti pendapat Abduh, Rasyid Ridha--murid Abduh yang paling setia-, menyatakan bahwa taqlid buta akan melumpuhkan kemampuan Islam dalam menjawab tantangan modernitas. Menurutnya, perkembangan sistem hukum Islam yang modern merupakan prioritas dan titik awal yang fundamental. Akan tetapi modernisme Ridha, terutama pasca meninggalnya Abduh, perlahan-lahan tercover dengan sikap konservatifnya. Reaksinya terhadap pengaruh yang makin berkembang dari kultur liberal ala Barat, menyebabkannya makin kritis terhadap Barat. Pembaruan Islam menurut Ridha justru memulihkan kembali kedudukan khalifah, sebagaimana yang terjadi pada masa khulafa al-rasyidin dulu. Pandangan Ridha yang demikian ini tidak lepas dari keterbatasannya mengadakan kontak dengan pola pikir dunia Barat, yang antara lain disebabkan tidak dikuasainya bahasa Eropa, sementara karya-karya Barat yang diterjemahkan ke dalam bahasa Arab masih relatif sedikit.

Berbeda dengan Ridha, Ali Abdur Raziq, juga salah seorang murid Abduh, justru mengembangkan pemikiran gurunya dalam konteks sekularisme. Pokokpokok pikirannya tentang konsep negara dan sistem Pemerintahan, banyak menimbulkan kontroversi di kalangan pemikir muslim waktu itu. Pendapat Abdur Raziq dianggap sebagai jiplakan sekularisme Barat yang berakibat mengorbankan sepenuhnya pandangan dunia Islam serta melumpuhkan kekuasaan Islam dalam menghadapi Barat.

Menurut Munawir Sjadzali, Ali Abdur Raziq juga tidak berhasil membuktikan bahwa Nabi Muhammad tidak berbeda dengan para nabi sebelumnya, bahwa otoritas yang dijalankan oleh nabi semasa hidupnya bukanlah otoritas seorang kepala negara. Dia tidak mencermati bahwa dalam Islam terdapat 
seperangkat hukum-syari'ah---yang untuk melaksanakannya diperlukan suatu otoritas atau kekuasaan yang mampu menjamin ditaatinya hukum tersebut (Munawir Sjadzali, 1993: 208).

Maududi dan Sayid Qutb adalah dua pemikir pertama abad ke-20 yang menggunakan pengertian bahwa umat Islam adalah khalifah-khalifah Allah di bumi sebagai dasar teori negara. Keduanya menolak prinsip kedaulatan rakyat, dan bagi mereka umat manusia hanya pelaksana kedaulatan dan hukum Tuhan serta tidak dibenarkan menempuh kebijaksanaan politik, hukum dan sebagainya yang bertentangan dengan ajaran dan hukum Tuhan. Secara implisit maupun eksplisit, mereka berpendapat hanya orang Islam saja yang berhak menjadi kepala negara. Sampai di sini Qutb tidak memberikan konsep pengangkatan kepala negara.

Menurut Qutb, berdasarkan universalisme Islam dalam negara Islam tidak dikenal perbedaan suku dan ras namun dibenarkan perlakuan diskriminasi politik berdasarkan agama. Di antara pemikir lain, Maududi mungkin yang paling lengkap memberikan rincian beserta tata aturan dalam sistem pemerintahan. Termasuk keberadaan Majelis Syura yang berfungsi sebagai lembaga legislatif.

Namun demikian, sistem politik Islam yang paripurna tanpa harus melihat kepada sistem Barat seperti yang dijanjikannya juga tidak bisa mengatasi problem-problem politik kekinian. Sebagaimana Qutb, dalam pengangkatan khalifah diserahkan sepenuhnya kepada umat Islam. Namun tidak ada tawaran lebih lanjut tentang mekanisme seperti apa yang harus diterapkan. Begitu juga dalam masalah suksesi, hanya menyatakan bahwa umat Islam dapat memecat kepala negara yang gagal melaksanakan amanat umat. Lagi-lagi hanya sampai sini - sebagaimana al-Mawardi-, mekanisme impeachment tidak di rinci lebih jauh.

\section{Penutup}

Menurut penulis, pendapat Qutb maupun Maududi yang mengharuskan umat Islam yang menjabat sebagai khalifah di muka bumi ini, rasanya amat sulit untuk diterapkan dalam situasi dan kondisi saat ini. Dimana umat Islam saat ini, dalam berbagai aspek justru sedang sangat tergantung kepada bangsa non Islam. 
Terutama dalam bidang ilmu dan teknologi, Islam selalu tertinggal jauh dari non Islam. Apakah mungkin pemerintahan seperti itu bisa diterapkan di saat kondisi umat Islam terpuruk dalam minoritas ideologi maupun minoritas kualitasnya.

Menindaklanjuti corak respon mereka terhadap perkembangan pemikiran Barat, cara pandang para pemikir-pemikir di atas dapat diklasifikasikan dalam tiga paradigma yaitu; Pertama, paradigma tradisionalisme, yang meneruskan dan menghidupkan kembali prinsip-prinsip kenegaraan yang berkembang sebelumnya (terutama masa khulafa al-rasyidin). Paradigma ini tidak mutlak menolak pemikiran Barat,namun lebih mengutamakan penanaman kembali unsur-unsur Islam dalam sistem pemerintahan. Di antara tokoh-tokohnya adalah, Rasyid Ridha dan Abu Kalam Azad. Kedua, paradigma modernisme, akomodatif terhadap pemikiran Barat, baik dengan melakukan justifikasi dari nilai-nilai Islam maupun melakukan Islamisasi terhadap pemikiran Barat. Di antara tokoh-tokohnya, Muhammad Abduh dan Ali Abdur Raziq. Ketiga, paradigma fundamentalisme, menolak pemikiran Barat bahkan menganggapnya sebagai musuh politik dan budaya, tidak mengikuti paradigma tradisional, namun membuat konsep sendiri tentang pemikiran politik Islam. Di antara tokoh-tokohnya, Sayid Qutb dan Abul A'la al-Maududi.

Selain dari pendekatan paradigma di atas, penulis, sependapat dengan Munawir Sjadzali (1993: 204-208), membagi pola-pola pemikir politik di atas dalam tiga kelompok, pertama, kelompok yang mempertahankan syari'at Islam sebagai landasan negara, sehingga tidak diperlukan lagi sistem pemerintahan model Barat. Rasyid Ridha meskipun tidak sekeras tokoh fundamentalis (Sayid Qutb dan Maududi) dalam menolak Barat, namun mempunyai pola pikir yang sama untuk tetap berpegang pada sistem pemerintahan yang berlandaskan syari'ah Islam. Mereka sepakat bahwa Islam adalah agama yang lengkap dengan petunjuk yang mengatur segala aspek kehidupan termasuk politik, di sini ada pola “integratif" yang mana ada unsur unsur penyatuan dari dua komponen yaitu agama dan negara.

Kedua, yang berpendapat bahwa Islam adalah agama yang mengurusi hubungan antar manusia dengan Tuhan semata. Jadi segala sesuatu yang 
berhubungan dengan ketatanegaraan, sepenuhnya menjadi hak manusia tanpa campur tangan tuhan di dalamnya. Hal ini memunculkan pola "substantif atau sekularisasi”, di mana ada pemisahan yang jelas antara negara dan Agama. Ali Abd Raziq adalah tokoh yang paling terlihat mempertahankan pendapat ini.

Ketiga, tidak sependapat bahwa Islam adalah agama yang lengkap mengatur segala aspek kehidupan, termasuk politik, namun juga tidak sependapat bila ada pemisahan antara agama dan negara. Di dalam Islam terdapat seperangkat prinsip dan tata nilai moral dan etik bagi kesejahteraan hidup manusia, termasuk kehidupan berbangsa dan bernegara, yang untuk pelaksanaannya umat Islam bebas memilih sistem manapun (termasuk sistem Barat) (Munawir Sjadzali, 1993: 205). Nampaknya paradigma "simbiotik" ini lebih menawarkan pencerahan untuk kondisi kontemporer saat ini. Tokoh penganutnya adalah Muhammad Husain Haikal. Meskipun dalam kerangka berpikir yang berbeda serta tidak mempunyai konsepsi politik yang utuh, Abduh bisa digolongkan dalam kelompok ini.

\section{Daftar Pustaka}

Azhar, Muhammad. 1996. Filsafat Politik, Perbandingan antara Islam dan Barat, Jakarta: PT Raja Grofindo Persada.

El-Affendi, Abdelwahab. 2001. Masyarakat tak Bernegara, Kritik Teori Politik Islam, terj.Amiruddin Ar-Rani, Yogyakarta: LKiS.

Esposito, John L. 1990. Islam dan Politik, terj. Joesoef Sou'yb, Jakarta: Bulan Bintang.

Sjadzali, Munawir. 1993. Islam dan Tata Negara, ajaran sejarah dan pemikiran, Jakarta: UI Press

Syamsuddin, M. Din. 2000. “Antara yang Berkuasa dan yang Dikuasai, Refleksi Atas Pemikiran dan Praktek Politik Islam “,Jurnal Al-Jami’ah, Vol. 39, No.1 Januari-Juni. , 2001. Islam dan Politik Era Orde Baru, Jakarta: Logos.

Yusdani, 1997. "Pemikiran Politik Ali Abd Raziq", Jurnal Al-Mawarid edisi VI, Fakultas Syari'ah UII Yogyakarta 